\title{
Penerapan Model Pembelajaran Kooperatif Tipe Jigsaw disertai Media Mind Mapping untuk Meningkatkan Pemahaman Konsep Ilmu Alamiah Dasar Mahasiswa Akuntansi Universitas Ahmad Dahlan
}

\author{
Ariati Dina Puspitasari \\ Pendidikan Fisika FKIP Universitas Ahmad Dahlan \\ Jalan Prof. Dr. Soepomo, S.H. Janturan Yogyakarta 55164 \\ Surat-e: arie.dina04@yahoo.co.id
}

\begin{abstract}
Penelitian ini bertujuan untuk mengetahui pemahaman konsep mahasiswa Akuntansi UAD pada mata kuliah IAD dengan menerapkan model pembelajaran kooperatif tipe Jigsaw disertai media mindmapping. Metode yang digunakan dalam penelitian ini adalah penelitian tindakan kelas. Pengumpulan data dilakukan menggunakan tes yang berupa soal pemahaman konsep IAD. Hasil penelitian menunjukkan bahwa dengan menerapkan model pembelajaran kooperatif tipe Jigsaw disertai media mind mapping dapat meningkatkan pemahaman konsep mahasiswa akuntansi pada mata kuliah IAD dengan nilai rata-rata kelas pada siklus I adalah 62,125 dan nilai rata-rata kelas meningkat pada siklus 2 yaitu 73,5 .
\end{abstract}

\begin{abstract}
This study aimed to determine the concept understanding of IAD subject of accounting student of UAD, Jigsaw Cooperative Learning model was implemented and accompanied by mind mapping media. Class act research method was used in this study. Data was collected using concept understanding test form of IAD subject. The result of this study shows that there's an increase of student understanding level in IAD subject with class average value of cycle $I$ is 62,125 and 73,5 for the cycle 2 .
\end{abstract}

Kata kunci: Jigsaw, Mind Mapping, Pemahaman Konsep

\section{Pendahuluan}

Ilmu Alamiah Dasar (IAD) merupakan mata Kuliah Dasar Umum (MKDU) yang diberikan pada Fakultas Non-Eksakta di Perguruan Tinggi tak terkecuali di Universitas Ahmad Dahlan. Tujuan mata kuliah ini yaitu untuk membantu mahasiswa agar memiliki pemahaman konsep dasar dan wawasan yang luas dalam bidang Ilmu Pengetahuan Alam (IPA) dan Teknologi sehingga menjadi cukup peka, cepat tanggap dan dapat mengambil tindakan yang tepat dan bertanggung jawab terhadap berbagai masalah perkembangan IPA dan Teknologi di samping masalah sosial dan budaya yang ada di masyarakat sekitar. [I].

Berdasarkan hasil observasi dan wawancara dengan mahasiswa di program studi Akuntansi, Universitas Ahmad Dahlan bahwa image mata kuliah IAD ini tergolong mata kuliah yang sulit untuk dipahami karena basic akademis mahasiswa sebagian besar adalah ilmu sosial. Beban studi 3 SKS pada mata kuliah ini juga menjadi problem tersendiri karena mahasiswa jenuh jika materi pembelajaran disampaikan secara monoton tanpa ada aktifitas yang menarik bagi mahasiswa. Oleh sebab itu, diperlukan suatu model pembelajaran yang menarik yang berpusat pada aktifitas mahasiswa sehingga dapat membantu mereka untuk memahami konsep dasar IPA dan Teknologi dengan baik.

Model pembelajaran kooperatif tipe jigsaw telah terbukti dapat meningkatkan aktifitas belajar dan prestasi belajar siswa karena menuntut siswa untuk berperan penuh dalam pembelajaran sehingga menjadi pembelajaran yang menarik dan menyenangkan [2]. Berdasarkan masalah yang ada, maka peneliti tertarik untuk menerapkan model pembelajaran kooperatif tipe jigsaw disertai media mind mapping yang bertujuan untuk meningkatkan pemahaman konsep IAD pada mahasiswa Akuntansi UAD.

\section{Kajian Pustaka}

Pembelajaran kooperatif mempunyai beberapa tipe antara lain: (I) Student Team Achivement Division (STAD); (2) cooperative Integrated Readind and composition (CIRC); (3) Jigsaw; (4) Teams-Game- 
Tournamen (TGT); (5) Group Investigation; dan lainnya [3]. Dalam pembelajaran jigsaw dibutuhkan proses mendengarkan, keterikatan dan empati dari setiap anggota kelompok untuk menjalankan aktifitas pembelajaran sehingga tujuan pembelajaran dapat tercapai.

Terdapat I0 langkah dalam pembelajaran jigsaw ini. Yaitu (I) membagi siswa menjadi 5-6 grup dengan masing-masing grup terdiri dari 5-6 anggota (disebut kelompok asal); (2) menentukan pemimpin dalam setiap kelompok tersebut; (3) menentukan 5-6 tema untuk diskusi; (4) memberikan satu tema berbeda untuk setiap anggota kelompok; (5) meminta setiap anggota yang mempunyai tema sama untuk berkumpul dan disebut kelompok ahli; (6) diskusi kelompok ahli untuk membahas tema yang telah ditentukan; (7) meminta siswa berkumpul kembali ke kelompok asal; (8) setiap anggota kelompok mempresentasikan hasil diskusi dalam kelompok ahli; (9) memberikan konfirmasi dan klarifikasi antar grup; (I0) memberikan kuis atau tugas [4].

Mind mapping adalah sebuah cara yang efektif untuk mencatat dan mengungkapkan gagasan dalam sebuah topik. Penulisan mind mapping dilakukan dengan melakukan penulisan dari tema utama kemudian menuliskan gagasan baru/katakunci terkait tema tersebut, dilanjutkan dengan mencari hubungan antara kata kunci satu dengan yang lainnya, sehingga dapat membantu mengetahui dan menyimpan informasi dengan baik [5].

\section{Metode Penelitian/Eksperimen}

Jenis penelitian ini adalah Penelitian Tindakan Kelas (PTK). Penelitian ini dilaksanakan di Program Studi Akuntansi Universitas Ahmad Dahlan pada semester Genap 2015/2016 dalam 2 (dua) siklus. Setiap siklus terdapat aktifitas perencanaan, tindakan, observasi, refleksi. Berikut adalah diagram siklus [6] pada penelitian ini

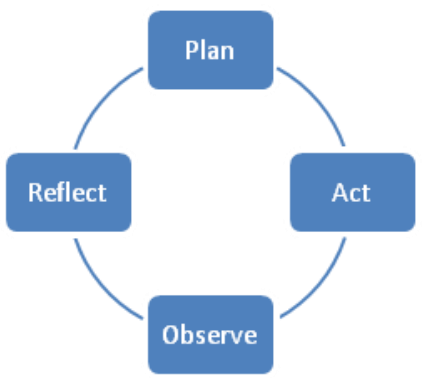

Gambar I. Siklus Penelitian Tindakan Kelas

Tahap pertama adalah perencanaan (Plan), yaitu merancang pembelajaran dengan menggunakan model pembelajaran kooperatif tipe jigsaw disertai mindmapping dan instrumen penilaian. Tahap kedua adalah pelaksanaan pembelajaran dengan menerapkan rencana pembelajaran yang telah disiapkan. Tahap ketiga adalah melakukan
Penerapan Model Pembelajaran Kooperatif Tipe Jigsaw disertai Media Mind Mapping untuk Meningkatkan Pemahaman Konsep Ilmu Alamiah Dasar Mahasiswa Akuntansi Universitas Ahmad Dahlan

pengamatan terhadap variabel yang diukur. Tahap keempat adalah refleksi dari rangkaian penelitian.

Pelaksanaan siklus kedua apabila belum didapatkan pemahaman konsep yang baik pada siklus pertama. Pemahaman konsep yang baik dinyatakan apabila nilai rata-rata kelas mencapai 70 . Teknik pengumpulan data digunakan melalui tes pemahaman konsep mahasiswa. Jumlah subyek penelitian adalah 40 mahasiswa program studi akuntansi.

\section{Hasil Penelitian dan Pembahasan}

Penelitian ini bertujuan untuk menerapkan model pembelajaran kooperatif tipe Jigsaw disertai media mind mapping untuk meningkatkan pemahaman konsep mahasiswa akuntansi pada matakuliah Ilmu Alamiah Dasar. Hasil penelitian pada siklus I yaitu,

\section{Tahap Perencanaan}

Pada tahap ini, peneliti mempersiapkan seluruh instrumen dan kebutuhan pembelajaran yang akan dilaksanakan.

\section{Tahap Pelaksanaan}

Pada tahap pelaksanaan, peneliti menerapkan model pembelajaran jigsaw dengan membagi mahasiswa menjadi 5 kelompok, setelah itu setiap anggota dalam kelompok diberikan tema yang berbeda. Setiap mahasiswa yang mempunyai tema sama akan berkumpul dan berdiskusi sebagai kelompok ahli. Outcome dari diskusi kelompok ahli berupa mind mapping yang akan digunakan saat presentasi/menjelaskan di kelompok asal. Tahap ini dilaksanakan dalam 2 kali pertemuan.

\section{Tahap Observasi}

Pada tahap ini mahasiswa diberikan tes berupa soal-soal IAD. Berikut adalah data hasil pemahaman konsep mahasiswa terhadap mata kuliah Ilmu Alamiah Dasar.

\begin{tabular}{ccccc}
\multicolumn{5}{c}{ Tabel I. Pemahaman Konsep IAD Siklus I } \\
\hline $\begin{array}{c}\text { Jumlah } \\
\text { mahasiswa }\end{array}$ & $\begin{array}{c}\text { Skor } \\
\text { total }\end{array}$ & $\begin{array}{c}\text { Nilai } \\
\text { rata-rata }\end{array}$ & $\begin{array}{c}\text { Banyak } \\
\text { mahasiswa } \\
\text { nilai }<70\end{array}$ & Prosentase \\
\hline \hline 40 & 2485 & 62,125 & $\mathrm{I} 4$ & $35 \%$ \\
\hline
\end{tabular}


Penerapan Model Pembelajaran Kooperatif Tipe Jigsaw disertai Media Mind Mapping untuk Meningkatkan Pemahaman Konsep Ilmu Alamiah Dasar Mahasiswa Akuntansi Universitas Ahmad Dahlan

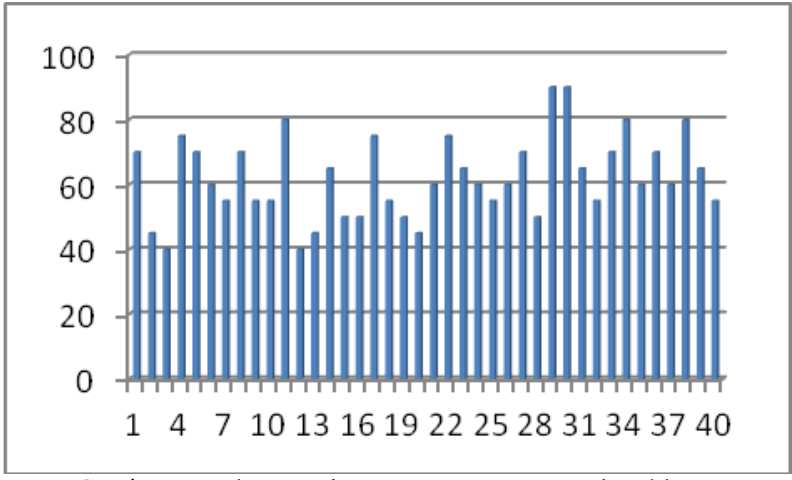

Gambar 2. Nilai Pemahaman Konsep IAD pada Siklus I

Berdasarkan data diatas nilai rata-rata kelas belum mencapai target pembelajaran atau pemahaman konsep yang baik.

\section{Tahap Refleksi}

Pada tahap ini, dilakukan refleksi terhadap proses pembelajaran siklus I. Berdasarkan rata-rata nilai mahasiswa yang masih dibawah 70, maka penelitian ini dilanjutkan pada siklus 2 dengan beberapa perbaikan. Perbaikan didapatkan dari hasil wawancara atau sharing dengan mahasiswa. Berdasarkan hasil wawancara tersebut, perbaikan yang akan dilakukan pada siklus 2 adalah pembagian kelompok akan diubah, jika pada siklus I kelompok asal terdiri dari 8 mahasiswa dan kelompok ahli 5 mahasiswa, maka pada siklus kedua kelompok asal 5 mahasiswa dan kelompok ahli 8 mahasiswa. Dengan harapan presentasi di kelompok asal akan lebih fokus karena lebih sedikit anggota.

Hasil penelitian pada siklus 2 adalah sebagai berikut,

\section{Tahap Perencanaan}

Peneliti mempersiapkan semua instrumen yang akan digunakan dalam pembelajaran siklus 2 , seperti instrumen penilaian, tema diskusi dan kuis.

\section{Tahap Pelaksanaan}

Peneliti melaksanakan kegiatan sesuai yang telah direncanakan. Membagi kelompok asal menjadi 8 kelompok dengan masing-masing anggota kelompok 5 mahasiswa. Memberikan kepada masing-masing anggota kelompok di setiap kelompok tema yang berbeda. Setiap mahasiswa yang mendapat tema sama akan berkumpul, berdiskusi dan membuat mind mapping.

\section{Tahap Observasi}

Pada tahap ini mahasiswa diberikan tes berupa soal-soal IAD. Berikut adalah data hasil pemahaman konsep mahasiswa pada siklus 2,
Tabel 2. Pemahaman Konsep IAD Siklus 2

\begin{tabular}{ccccc}
\hline $\begin{array}{c}\text { Jumlah } \\
\text { mahasiswa }\end{array}$ & $\begin{array}{c}\text { Skor } \\
\text { total }\end{array}$ & $\begin{array}{c}\text { Nilai } \\
\text { rata-rata }\end{array}$ & $\begin{array}{c}\text { Banyak } \\
\text { mahasiswa } \\
\text { nilai }<70\end{array}$ & Prosentase \\
\hline \hline 40 & 2940 & 73,5 & 34 & $85 \%$ \\
\hline
\end{tabular}

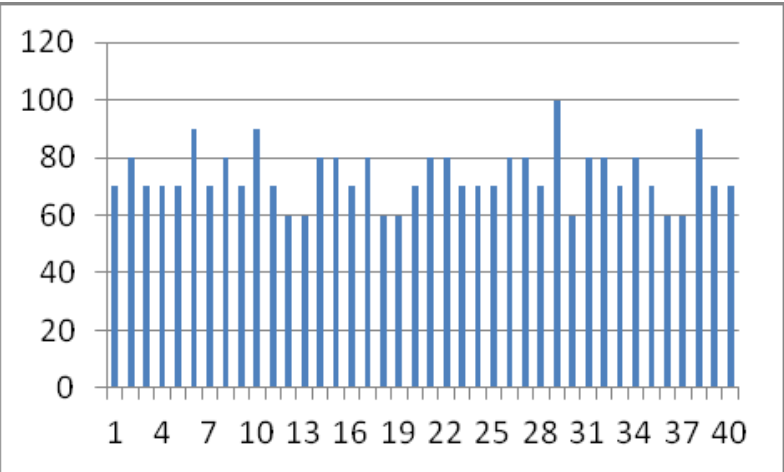

Gambar 3. Nilai Pemahaman Konsep IAD pada Siklus 2

\section{Tahap Refleksi}

Berdasarkan data hasil pengamatan diatas, nilai rata-rata kelas pada pemahaman konsep mahasiswa telah memenuhi target, ditambah lagi dengan sebanyak 34 mahasiswa yang mendapatkan nilai minimal 70 .

Model pembelajaran tipe jigsaw yang dikombinasi dengan media mindmapping dapat meningkatkan pemahaman konsep mahasiswa akuntansi pada mata kuliah IAD. Karena model pembelajaran ini menuntut adanya kerjasama yang baik oleh setiap anggota kelompok untuk dapat saling memahamkan anggota lainnya dengan cara yang menyenangkan dan mudah dipahami.

\section{Kesimpulan}

Hasil penelitian ini menyimpulkan bahwa dengan menerapkan model pembelajaran kooperatif tipe Jigsaw disertai media mind mapping dapat meningkatkan pemahaman konsep mahasiswa akuntansi pada mata kuliah IAD dengan nilai rata-rata kelas pada siklus I adalah 62,125 dan nilai rata-rata kelas meningkat pada siklus 2 yaitu 73,5.

\section{Ucapan Terimakasih}

Terimakasih diucapkan kepada prodi pendidikan akuntansi UAD dan tim pengajar IAD FKIP UAD sehingga penelitian in dapat berjalan dengan lancar. 
Penerapan Model Pembelajaran Kooperatif Tipe Jigsaw disertai Media Mind Mapping untuk Meningkatkan Pemahaman Konsep Ilmu Alamiah Dasar Mahasiswa Akuntansi Universitas Ahmad Dahlan

\section{Kepustakaan}

[I] Abdullah Aly dan Eny Rahma. 2014. Ilmu Alamiah Dasar. Jakarta: PT Bumi Aksara

[2] Rosmiati. 2013. Penerapan model Pembelajaran Koopeatif Tipe Jigsaw Pada materi Pokok Gerak Untuk meningkatkan Aktifitas dan Prestasi belajar Fisika Siswa kelas VII SMP Negeri 2I Mataram. Surabaya: Proceeding Seminar Nasional Sains

[3] Slavin, R.E. 2009. Cooperative Learning (Teori, Riset, dan Praktik). Bandung: Nusa Media

[4]_. 2016. The Jigsaw Classroom. Diunduh dari www.jigsaw.org

[5] Walton Hall\&Milton Keynes. 2005. Mind Mapping. The University of Adelide. https://www.adelaide.edu.au/writingcentre/learning_guides/le arningGuide_mindMapping.pdf 